\title{
Ecomorphological correlates of twenty dominant fish species of Amazonian floodplain lakes
}

\author{
F. K. Siqueira-Souza ${ }^{a}$, C. Bayer ${ }^{b}$, W. H. Caldas ${ }^{c}$, D. C. Cardoso ${ }^{a}$, \\ K. C. Yamamoto ${ }^{a}$ and C. E. C. Freitas ${ }^{a *}$ \\ aDepartamento de Ciências Pesqueiras, Universidade Federal do Amazonas - UFAM, Av. General Rodrigo Otávio Jordão \\ Ramos, 6200, Campus Universitário, CEP 69077-000, Manaus, AM, Brazil

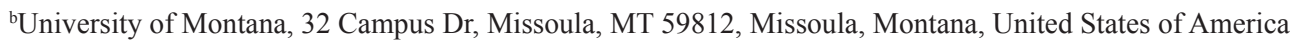 \\ 'Instituto Nacional de Pesquisas da Amazônia, Av. André Araújo, 2936, Petrópolis, CEP 69067-375, Manaus, AM, Brazil \\ *e-mail: cefreitas@ufam.edu.br
}

Received: October 6, 2015 - Accepted: December 15, 2015 - Distributed: February 28, 2017

(With 3 figures)

\begin{abstract}
Fishes inhabiting Amazonian floodplain lakes exhibits a great variety of body shape, which was a key advantage to colonize the several habitats that compose these areas adjacent to the large Amazon rivers. In this paper, we did an ecomorphological analysis of twenty abundant species, sampled in May and August 2011, into two floodplain lakes of the lower stretch of the Solimões River. The analysis detected differences among species, which could be probably associated with swimming ability and habitat use preferences.
\end{abstract}

Keywords: ecomorphology, Amazon fish, swimming ability, habitat use.

\section{Correlações ecomorfológicas de vinte espécies de peixes dominantes em lagos de várzea da Amazônia}

\section{Resumo}

Os peixes que habitam os lagos de várzea da Amazônia apresentam morfologias bastante diversas, possibilitando a exploração bem sucedida dos diferentes habitats que formam estas áreas adjacentes aos grandes rios amazônicos. Neste artigo, relatamos os resultados de uma análise ecomorfológica de vinte espécies abundantes, coletadas em maio e agosto de 2011, em dois lagos das várzeas do trecho inferior do rio Solimões. As analises indicaram diferenças entre as espécies como função do atributos ecomorfológicos, provavelmente associadas com a capacidade natatória e com preferências por habitat.

Palavras-chave: ecomorfologia, peixes da Amazônia, capacidade natatória, preferência por habitat.

\section{Introduction}

Amazonian floodplain lakes are complex environments, whose spatial heterogeneity spans such distinct habitats as flooded forests, macrophyte meadows and open water. These habitats provide areas used by several fish species for shelter, feeding, growth and reproduction during different phases of their life cycles (Saint-Paul et al., 2000; Sánchez-Botero and Araújo-Lima, 2001; Freitas and Garcez, 2004; Siqueira-Souza and Freitas, 2004). A seasonal component adds additional complexity to floodplain lake habitat by changing the availability of these habitats to fish over the course of the year. The monomodal flood pulse present in the Amazon basin promotes substantial alterations of the floodplain lakes with a difference between maximum and minimum water levels of approximately $15 \mathrm{~m}$, a change which substantially modifies the dimensional

and physical-chemical characteristics of the water bodies (Junk et al., 1989; Alsdorf et al., 2000).

A diverse assemblage of fish species containing a large spectrum of morphologies and feeding behaviors has colonized this heterogeneous environment. This environmental spatial heterogeneity imposes scales and is responsible for a nested model of diversity (Freitas et al., 2014), which needs to be considered in studies of fish ecology. This high environmental heterogeneity favored the establishment of a large diversity of fish, which have developed several adaptations through evolutive process. These adaptations include aspects of their morphologies related to swimming across the open water or to maneuvering within the dense structures of macrophyte meadows and flooded forests.

The floodplain lakes of the Central Amazon are relatively well preserved. There are no hydroelectric 
dams in this area and the human population density is low in comparison with other areas, such as the southern Amazon. There are no introduced species present in the floodplain lakes of the Central Amazon, and the main impact on its fish fauna is a small-scale fishery. This fishery is several decades old and, while over exploitation of some populations has occurred (Campos et al., 2015), there is no evidence that the fish assemblage of these lakes has changed as a result. The relatively pristine nature of these floodplain lakes makes them an ideal location to search for ecomorphological patterns explaining habitat use in their resident fish species.

The central idea of ecomorphology is that the morphological design of a fish species should define its ability to perform essential activities necessary to its survival (Gatz Junior, 1979). Several studies had established the importance of body size, shape and specific morphological measures on swimming ability (Breda et al., 2005; Cunico and Agostinho, 2006), habitat use (Motta et al., 1995; Freitas et al., 2005) and feeding behavior (Motta et al., 1995; Hugueny and Pouilly, 1999; Pouilly et al., 2003; Freitas et al., 2005; Mazzoni et al., 2010; Neves et al., 2015). In this study, we measured the ecomorphological correlates of twenty dominant fish species of Amazonian floodplain lakes (Saint-Paul et al., 2000; Siqueira-Souza and Freitas, 2004; Santos et al., 2006; Soares et al., 2007) in order to identify groups of species with specific morphological features and relate them to ecological aspects of feeding behavior and habitat preference.

\section{Material and Methods}

\subsection{Study area}

The study area was comprised of two floodplain lakes in a lower stretch of the Solimões River, downstream of the Purus River mouth and above the confluence of the Solimões and Negro rivers (Figure 1). The floodplain lakes are known as: Calado $(-3.3939 \mathrm{~S},-60.2447 \mathrm{~W})$, which has an area of $2.12 \mathrm{~km}^{2}$, and Camboa (-3.3562S, -60.6258W), which has an area of $0.98 \mathrm{~km}^{2}$. These water bodies are typical floodplain lakes which remain connected with the main river channel for several months of the year and are greatly affected by the annual flood pulse.

\subsection{Data sampling and analyzed species}

Samples were taken in May and August 2011 during the flooded season in three habitats types: open water; mixed aquatic macrophytes, composed predominantly by Pistia stratiotes, Eichhornia crassipes, Echinochloa polystachya, Paspalum repens, P. fasciculatum and Salvinia auriculata; and flooded forest, which is used by several species as a shelter and feeding ground. Fish were collected using ten monofilament gillnets of standardized dimensions, $15 \mathrm{~m}$ long $\mathrm{x} 2 \mathrm{~m}$ width, and different mesh size of 30, 40, $50,60,70,80,90,100,110$ and $120 \mathrm{~mm}$ of stretch size. Each lake was sampled for a total of 48 hours. To prevent sample loss through the predation of enmeshed fish, gill nets were checked and all fish removed every six hours.

Following identification, at least five individuals of the twenty species of interest were weighed and measured. When possible, morphological measurements

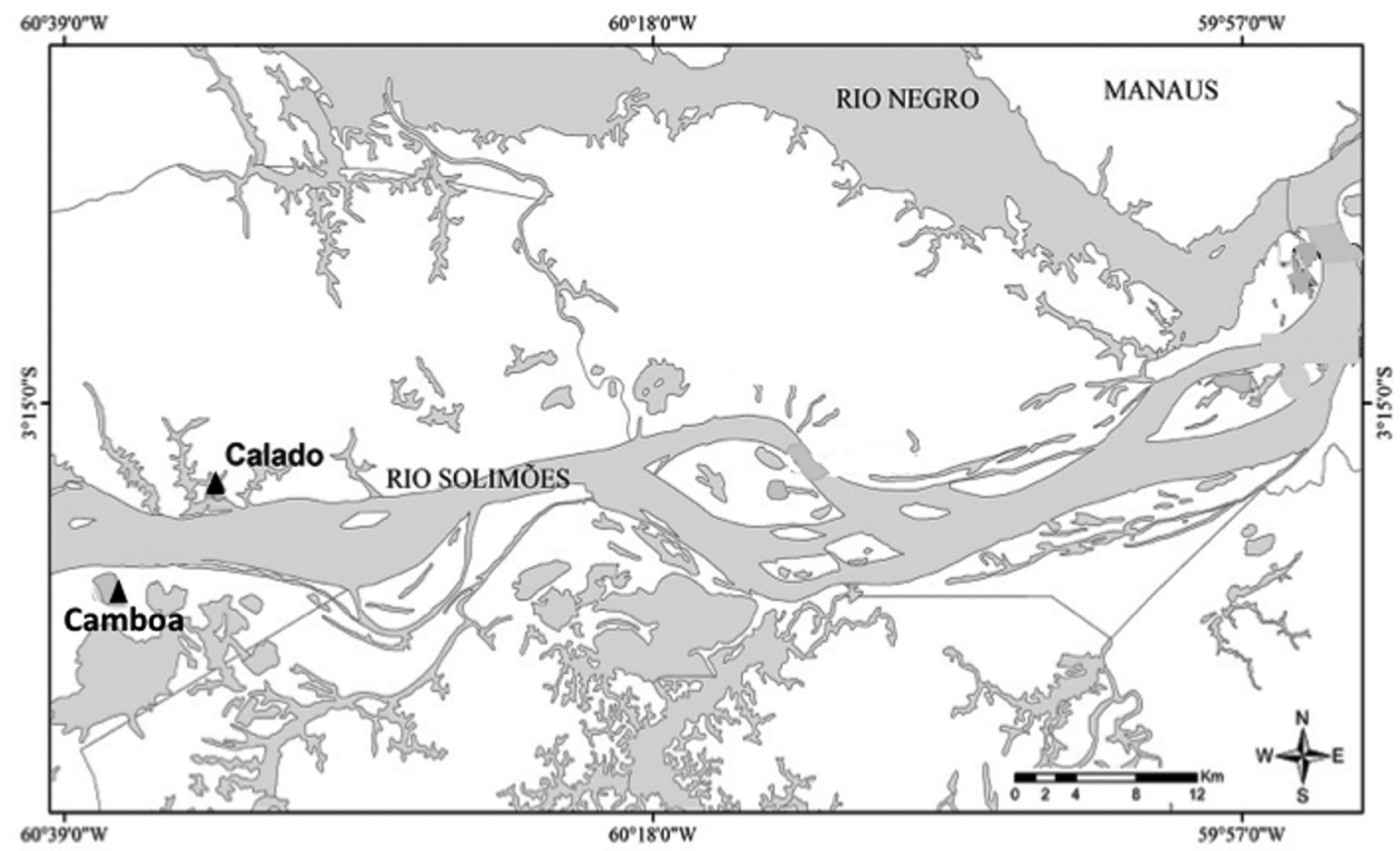

Figure 1. Map of study area highlighting the two lakes where the samples were done: Calado and Camboa. 
were taken in the field. When time constraints prevented measurement in the field, or when the identification of a fish was in question, specimens were preserved in ice for later analysis at the Fisheries Ecology Laboratory of the Federal University of Amazonas.

The species included in our analysis are exclusively of non-carnivores, mainly detritivorous or omnivorous (Table 1), the two most abundant feeding groups in the Amazon Basin (Saint-Paul et al., 2000; Freitas et al., 2010). These feeding groups are highly important for the Amazonian fisheries and consist of more than $90 \%$ of the regional fishing catch (Batista and Petrere Júnior, 2003).

\subsection{Morphological measures and ecomorphological attributes}

For each species of interest we took the following morphological measurements: standard length (SL), maximum body width (MBW), maximum body depth (MBD), mean body height (MHB), maximum length of pectoral fin (MLF), caudal peduncle height (CPH), peduncle width $(\mathrm{PW})$, head height $(\mathrm{HH})$, maximum width of fin (MW) and eye height (EH) (Figure 2).

Using the above morphological measures we estimated nine ecomorphological attributes, namely:

1) Compression index (CI): the maximum body depth (MBD) divided by the maximum body width (MBW). High CI values indicate laterally compressed fishes inhabiting environments with slow flowing waters (Gatz Junior, 1979; Watson and Balon, 1984).

2) Relative depth (RD): the maximum body depth (MBD) divided by the standard length (SL). RD is inversely related to water velocity and directly related to a fish's ability to perform vertical movements (Gatz Junior, 1979).

3) Caudal peduncle compression index (CPC): Caudal peduncle heinght $(\mathrm{CPH})$ divided by standard length (SL). A compressed peduncle indicates a slow swimming speed and low maneuverability (Gatz Junior, 1979).

4) Pectoral aspect fin (PAF): maximum length of fin (MLF) divided by maximum width of pectoral fin (MW). A high ratio indicates a long and narrow pectoral fin, which is expected in fish that swim a great deal (Keast and Webb, 1966).

5) Flattening Ventral Index (FVI): proportion of body depth below the midline, estimated making the mean body height (MHB) divided by maximum body depth (MBD). Low estimates of FVI are associated with fishes living in fast flowing water. A Low FVI assists fishes with maintaining their position without swimming (Gatz Junior, 1979).

6) Relative width of caudal peduncle (RWCP): the peduncle width (PW) divided by the maximum body width (MBW). Higher relative values indicate better continuous swimmers (Winemiller, 1991).

7) Relative height of caudal peduncle (RHCP): the caudal peduncle height $(\mathrm{CPH})$ divided by the maximum body depth (MBD). Lower values indicate greater maneuverability potential (Oliveira et al., 2010; Winemiller, 1991).

Table 1. List of studied fish species, with respective code, sample size $(\mathrm{N})$ and feeding behavior.

\begin{tabular}{|c|c|c|c|c|}
\hline Family & Species & Code & $\mathbf{N}$ & Feeding Behavior \\
\hline Anostomidae & Leporinus friderici & lef & 14 & Omnivore $^{\mathrm{a}}$ \\
\hline Anostomidae & Leporinus trifasciatus & let & 10 & Frugivore $^{\mathrm{b}}$ \\
\hline Anostomidae & Rhythiodus microlepis & rhm & 11 & Leaf eater ${ }^{\mathrm{a}}$ \\
\hline Anostomidae & Schizodon fasciatus & $\operatorname{scf}$ & 13 & Herbivore $^{\mathrm{a}}$ \\
\hline Callichthyidae & Hoplosternum litoralle & hol & 6 & Leaf eater ${ }^{\mathrm{a}}$ \\
\hline Characidae & Brycon amazonicus & bra & 28 & Aquatic invert ${ }^{\mathrm{b}}$ \\
\hline Characidae & Colossoma macropomum & com & 15 & Omnivore $^{\mathrm{a}}$ \\
\hline Characidae & Mylossoma aureum & mya & 27 & Omnivore $^{\mathrm{b}}$ \\
\hline Characidae & Mylossoma duriventre & myd & 25 & Herbivore $^{\mathrm{a}}$ \\
\hline Characidae & Piaractus brachypomus & pib & 6 & Frugivore $^{\mathrm{b}}$ \\
\hline Characidae & Triportheus albus & tra & 69 & Frugivore $^{\mathrm{b}}$ \\
\hline Characidae & Triportheus elongatus & tre & 25 & Unsp. Herbivore ${ }^{b}$ \\
\hline Cichlidae & Mesonauta festivus & mef & 9 & Insetivore $^{\mathrm{a}}$ \\
\hline Curimatidae & Potamorhina altamazonica & poa & 59 & Omnivore $^{\mathrm{a}}$ \\
\hline Curimatidae & Potamorhina latior & pol & 48 & Detritivore $^{\mathrm{a}}$ \\
\hline Curimatidae & Psectrogaster rutiloides & psr & 39 & Detritivore $^{\mathrm{b}}$ \\
\hline Hemiodontidae & Anodus elongates & anl & 29 & Plants/detritus ${ }^{\mathrm{a}}$ \\
\hline Hemiodontidae & Hemiodus immaculatus & hei & 46 & Planktivore $^{\mathrm{a}}$ \\
\hline Prochilodontidae & Prochilodus nigricans & prn & 12 & Insectivore $^{\mathrm{a}}$ \\
\hline Prochilodontidae & Semaprochilodus insignis & pei & 24 & Detritivore $^{a}$ \\
\hline
\end{tabular}

${ }^{\mathrm{a}}$ Froese and Pauly (2015); ${ }^{\mathrm{b}}$ Mérona and Rankin-de-Mérona (2004). 


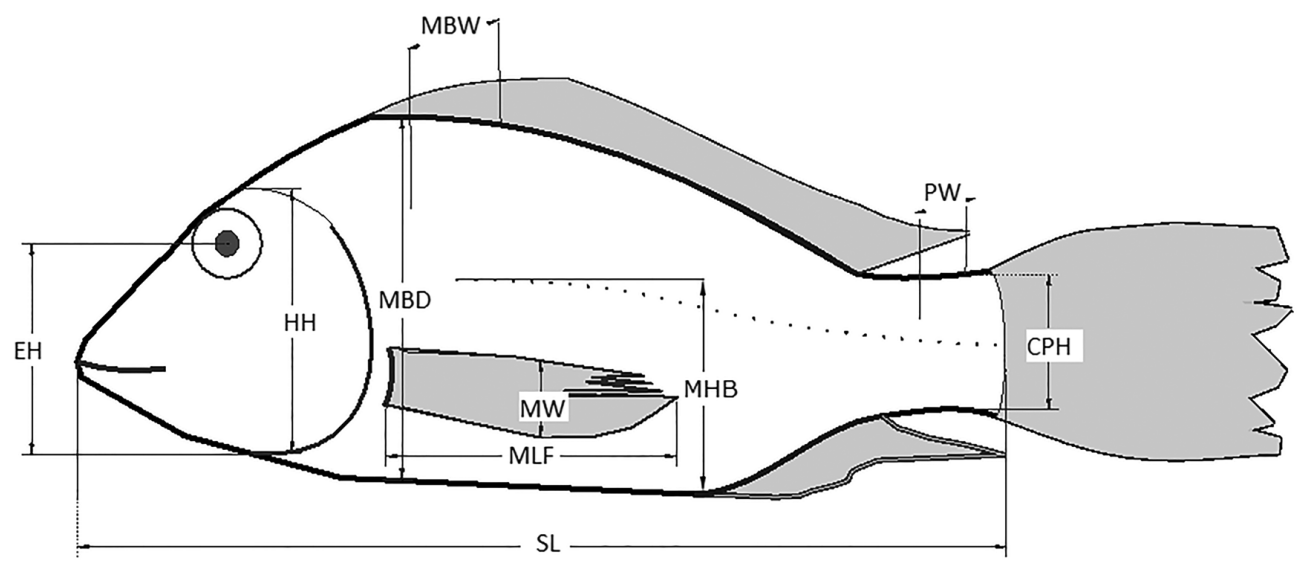

Figure 2. Schematic figure of a fish showing how the morphological measures were taken. The codes are: SL - standard length, MBW - maximum body width, MBD - maximum body depth, MHB - mean body height, MLF - maximum length of pectoral fin, $\mathrm{CPH}$ - caudal peduncle height, $\mathrm{PW}$ - peduncle width, $\mathrm{HH}$ - head height, $\mathrm{MW}$ - maximum width of fin and $\mathrm{EH}$ - eye height.

8) Relative height of head (RHH): the head height (HH) divided by the maximum body depth (MBD). Greater values of relative head height are found in fishes that feed on larger prey (Winemiller, 1991).

9) Vertical Eye Position (VEP): estimated as eye height (EH) divided by the head height $(\mathrm{HH})$. VEP is associated with a fish's foraging position in the water column. This attribute can reveal a fish species' preferred position at the water column. Higher values are associated with benthic species and lower values with nektonic species (Gatz Junior, 1979; Watson and Balon, 1984; Freire and Agostinho, 2001).

\subsection{Data analysis}

Our ecomorphological attribute estimates did not follow a normal distribution; therefore, we normalized the data employing a square-root transformation before running a Linear Discriminant Analysis (LDA). Our null hypothesis was that there are no differences between fish species based on ecomorphology. To test this hypothesis we used species as a grouping variable and ecomorphological attributes as the independent variables. After our null hypothesis was rejected, we used a paired comparison $(\alpha$-level $=0.05)$ using the squared Mahalanobis distance to discriminate between different groups. We then used a Principal Component Analysis (PCA), based on a covariance matrix, to show the species ordered by their ecomorphological attributes. All statistical analyses were developed using the R software (R Core Team, 2013).

\section{Results}

The estimated mean of the ecomorphological attributes for each species and their standard deviations are showed in the Table 2. The Linear Discriminant Analysis showed that there are differences among these twenty species based on their ecomorphological attributes (Wilk's $\lambda=0.0019$, $\mathrm{df}=162,3904, \mathrm{p}<0.001)$ with each of the nine attributes being significant (Table 3 ). Paired comparison employing squared Mahalanobis distance showed significant differences between all of the species except: Colossoma macropomum and Piaractus brachypomus $(\mathrm{p}=0.931)$, Leporinus friderici and L. trifasciatus $(\mathrm{p}=0.962)$, and Triportheus albus and T. elongatus $(\mathrm{p}=0.679)$. All other paired comparisons were significant to $\mathrm{p}<0.01$.

The first principal component represented $68.38 \%$ of the variance and produced two groups of species based on their hydrodynamics. PCA1 mainly represented species' agility and swimming ability. Species to the right side of this axe are Mylossoma aureum (mya), M. duriventre (myd), Piaractus brachypomus (pib), Colossoma macropomum (com) and Mesonauta festivus (mef) (Figure 3). These species are associated with high estimates of CI, RD, CPC and VEP attributes. Their bodies are laterally compressed, with low swimming ability but with the potential for vertical movements. Species grouped to the left side of the axis are Hoplosternum litoralle (hol), Anodus elongatus (anl), Rhythiodus microlepis (rhm), Hemiodus immaculatus (hei), Leporinus trifasciatus (let), L. friderici (lef), and Schizodon fasciatus (scf) (Figure 3). These species are associated with RHH, RWCP and RHCP (Figure 2). With exception of $H$. litoralle (hol), this group is composed of species that have a hydrodynamic body and are good swimmers. The second principal component, which explained $15.81 \%$ of the variance, was able to discriminate between Triportheus albus (tra) and T. elongatus (tre), in the upper portion of the graph associated with PAF (Figure 3). This principal component also demonstrated that Hoplosternum littorale (hol) and Rhythiodus microlepis (rhm) were slightly associated with Flattening Ventral Index (FVI), probably as a consequence of these species' preference for benthic areas. 
Table 2. Means and standard deviations (between parentheses) of the ecomorphological attributes.

\begin{tabular}{|c|c|c|c|c|c|c|c|c|c|}
\hline $\begin{array}{l}\text { Species } \\
\text { code }\end{array}$ & CI & RD & СРC & PAF & FVI & RWCP & RHCP & RHH & VEP \\
\hline anl & $\begin{array}{l}1.698 \\
(0.26)\end{array}$ & $\begin{array}{l}0.205 \\
(0.01)\end{array}$ & $\begin{array}{l}1.805 \\
(0.34)\end{array}$ & $\begin{array}{l}1.130 \\
(0.24)\end{array}$ & $\begin{array}{l}0.584 \\
(0.06)\end{array}$ & $\begin{array}{l}0.311 \\
(0.06)\end{array}$ & $\begin{array}{l}0.324 \\
(0.02)\end{array}$ & $\begin{array}{l}0.748 \\
(0.13)\end{array}$ & $\begin{array}{l}0.625 \\
(0.11)\end{array}$ \\
\hline bra & $\begin{array}{l}2.304 \\
(0.33)\end{array}$ & $\begin{array}{l}0.352 \\
(0.04)\end{array}$ & $\begin{array}{l}2.264 \\
(0.54)\end{array}$ & $\begin{array}{l}1.296 \\
(0.22)\end{array}$ & $\begin{array}{l}0.472 \\
(0.07)\end{array}$ & $\begin{array}{l}0.297 \\
(0.10)\end{array}$ & $\begin{array}{l}0.273 \\
(0.03)\end{array}$ & $\begin{array}{l}0.663 \\
(0.09)\end{array}$ & $\begin{array}{l}0.781 \\
(0.07)\end{array}$ \\
\hline com & $\begin{array}{l}3.596 \\
(0.40)\end{array}$ & $\begin{array}{l}0.562 \\
(0.04)\end{array}$ & $\begin{array}{l}2.370 \\
(0.54)\end{array}$ & $\begin{array}{l}1.397 \\
(0.14)\end{array}$ & $\begin{array}{l}0.532 \\
(0.02)\end{array}$ & $\begin{array}{l}0.293 \\
(0.09)\end{array}$ & $\begin{array}{l}0.182 \\
(0.02)\end{array}$ & $\begin{array}{l}0.544 \\
(0.04)\end{array}$ & $\begin{array}{l}0.748 \\
(0.03)\end{array}$ \\
\hline hei & $\begin{array}{l}1.775 \\
(0.18)\end{array}$ & $\begin{array}{l}0.250 \\
(0.01)\end{array}$ & $\begin{array}{l}1.942 \\
(0.33)\end{array}$ & $\begin{array}{l}0.999 \\
(0.12)\end{array}$ & $\begin{array}{l}0.547 \\
(0.05)\end{array}$ & $\begin{array}{l}0.303 \\
(0.05)\end{array}$ & $\begin{array}{l}0.325 \\
(0.02)\end{array}$ & $\begin{array}{l}0.637 \\
(0.04)\end{array}$ & $\begin{array}{l}0.705 \\
(0.04)\end{array}$ \\
\hline hol & $\begin{array}{l}1.282 \\
(0.13)\end{array}$ & $\begin{array}{l}0.305 \\
(0.01)\end{array}$ & $\begin{array}{l}2.229 \\
(0.19)\end{array}$ & $\begin{array}{l}1.012 \\
(0.09)\end{array}$ & $\begin{array}{l}0.687 \\
(0.05)\end{array}$ & $\begin{array}{l}0.270 \\
(0.03)\end{array}$ & $\begin{array}{l}0.467 \\
(0.02)\end{array}$ & $\begin{array}{l}0.817 \\
(0.02)\end{array}$ & $\begin{array}{l}0.708 \\
(0.11)\end{array}$ \\
\hline lef & $\begin{array}{l}1.947 \\
(0.36)\end{array}$ & $\begin{array}{l}0.311 \\
(0.02)\end{array}$ & $\begin{array}{l}2.010 \\
(0.32)\end{array}$ & $\begin{array}{l}1.047 \\
(0.20)\end{array}$ & $\begin{array}{l}0.620 \\
(0.05)\end{array}$ & $\begin{array}{l}0.329 \\
(0.06)\end{array}$ & $\begin{array}{l}0.338 \\
(0.03)\end{array}$ & $\begin{array}{l}0.679 \\
(0.03)\end{array}$ & $\begin{array}{l}0.775 \\
(0.04)\end{array}$ \\
\hline let & $\begin{array}{l}1.909 \\
(0.25)\end{array}$ & $\begin{array}{l}0.304 \\
(0.02)\end{array}$ & $\begin{array}{l}1.935 \\
(0.36)\end{array}$ & $\begin{array}{l}1.046 \\
(0.12)\end{array}$ & $\begin{array}{l}0.586 \\
(0.09)\end{array}$ & $\begin{array}{l}0.340 \\
(0.08)\end{array}$ & $\begin{array}{l}0.337 \\
(0.08)\end{array}$ & $\begin{array}{l}0.675 \\
(0.03)\end{array}$ & $\begin{array}{l}0.808 \\
(0.04)\end{array}$ \\
\hline mef & $\begin{array}{l}3.392 \\
(0.38)\end{array}$ & $\begin{array}{l}0.530 \\
(0.03)\end{array}$ & $\begin{array}{l}5.103 \\
(0.87)\end{array}$ & $\begin{array}{l}1.550 \\
(0.17)\end{array}$ & $\begin{array}{l}0.452 \\
(0.12)\end{array}$ & $\begin{array}{l}0.231 \\
(0.04)\end{array}$ & $\begin{array}{l}0.341 \\
(0.03)\end{array}$ & $\begin{array}{l}0.641 \\
(0.06)\end{array}$ & $\begin{array}{l}0.768 \\
(0.06)\end{array}$ \\
\hline mya & $\begin{array}{l}5.660 \\
(0.86)\end{array}$ & $\begin{array}{l}1.010 \\
(0.36)\end{array}$ & $\begin{array}{l}3.090 \\
(0.47)\end{array}$ & $\begin{array}{l}1.800 \\
(0.27)\end{array}$ & $\begin{array}{l}0.562 \\
(0.12)\end{array}$ & $\begin{array}{l}0.249 \\
(0.03)\end{array}$ & $\begin{array}{l}0.132 \\
(0.03)\end{array}$ & $\begin{array}{l}0.328 \\
(0.07)\end{array}$ & $\begin{array}{l}0.778 \\
(0.06)\end{array}$ \\
\hline myd & $\begin{array}{l}4.846 \\
(0.94)\end{array}$ & $\begin{array}{l}0.719 \\
(0.11)\end{array}$ & $\begin{array}{l}2.661 \\
(0.47)\end{array}$ & $\begin{array}{l}1.540 \\
(0.27)\end{array}$ & $\begin{array}{l}0.564 \\
(0.04)\end{array}$ & $\begin{array}{l}0.245 \\
(0.05)\end{array}$ & $\begin{array}{l}0.137 \\
(0.05)\end{array}$ & $\begin{array}{l}0.377 \\
(0.04)\end{array}$ & $\begin{array}{l}0.822 \\
(0.05)\end{array}$ \\
\hline pib & $\begin{array}{l}3.883 \\
(0.41)\end{array}$ & $\begin{array}{l}0.591 \\
(0.02)\end{array}$ & $\begin{array}{l}2.606 \\
(0.91)\end{array}$ & $\begin{array}{l}1.550 \\
(0.14)\end{array}$ & $\begin{array}{l}0.526 \\
(0.04)\end{array}$ & $\begin{array}{l}0.297 \\
(0.08)\end{array}$ & $\begin{array}{l}0.184 \\
(0.02)\end{array}$ & $\begin{array}{l}0.557 \\
(0.06)\end{array}$ & $\begin{array}{l}0.783 \\
(0.04)\end{array}$ \\
\hline poa & $\begin{array}{l}2.278 \\
(0.21)\end{array}$ & $\begin{array}{l}0.334 \\
(0.03)\end{array}$ & $\begin{array}{l}2.375 \\
(0.45)\end{array}$ & $\begin{array}{l}1.205 \\
(.014)\end{array}$ & $\begin{array}{l}0.586 \\
(0.05)\end{array}$ & $\begin{array}{l}0.334 \\
(0.46)\end{array}$ & $\begin{array}{l}0.287 \\
(0.03)\end{array}$ & $\begin{array}{l}0.635 \\
(0.07)\end{array}$ & $\begin{array}{l}0.758 \\
(0.05)\end{array}$ \\
\hline pol & $\begin{array}{l}2.860 \\
(0.45)\end{array}$ & $\begin{array}{l}0.345 \\
(0.05)\end{array}$ & $\begin{array}{l}2.513 \\
(0.51)\end{array}$ & $\begin{array}{l}1.283 \\
(0.23)\end{array}$ & $\begin{array}{l}0.580 \\
(0.04)\end{array}$ & $\begin{array}{l}0.325 \\
(0.07)\end{array}$ & $\begin{array}{l}0.280 \\
(0.04)\end{array}$ & $\begin{array}{l}0.561 \\
(0.08)\end{array}$ & $\begin{array}{l}0.761 \\
(0.16)\end{array}$ \\
\hline prn & $\begin{array}{l}2.704 \\
(1.16)\end{array}$ & $\begin{array}{c}0.550 \\
(0.709)\end{array}$ & $\begin{array}{l}2.482 \\
(0.57)\end{array}$ & $\begin{array}{l}1.325 \\
(0.12)\end{array}$ & $\begin{array}{l}0.553 \\
(0.12)\end{array}$ & $\begin{array}{l}0.329 \\
(0.07)\end{array}$ & $\begin{array}{l}0.317 \\
(0.07)\end{array}$ & $\begin{array}{l}0.565 \\
(0.14)\end{array}$ & $\begin{array}{l}0.864 \\
(0.04)\end{array}$ \\
\hline $\mathrm{psr}$ & $\begin{array}{l}2.338 \\
(0.27)\end{array}$ & $\begin{array}{l}0.360 \\
(0.02)\end{array}$ & $\begin{array}{l}2.853 \\
(0.63)\end{array}$ & $\begin{array}{l}1.296 \\
(0.19)\end{array}$ & $\begin{array}{l}0.598 \\
(0.04)\end{array}$ & $\begin{array}{l}0.246 \\
(0.05)\end{array}$ & $\begin{array}{l}0.289 \\
(0.02)\end{array}$ & $\begin{array}{l}0.716 \\
(0.07)\end{array}$ & $\begin{array}{l}0.738 \\
(0.07)\end{array}$ \\
\hline $\mathrm{rhm}$ & $\begin{array}{l}1.782 \\
(0.35)\end{array}$ & $\begin{array}{l}0.215 \\
(0.02)\end{array}$ & $\begin{array}{l}1.962 \\
(0.20)\end{array}$ & $\begin{array}{l}1.102 \\
(0.16)\end{array}$ & $\begin{array}{l}0.668 \\
(0.08)\end{array}$ & $\begin{array}{l}0.360 \\
(0.05)\end{array}$ & $\begin{array}{l}0.401 \\
(0.05)\end{array}$ & $\begin{array}{l}0.635 \\
(0.07)\end{array}$ & $\begin{array}{l}0.756 \\
(0.06)\end{array}$ \\
\hline sei & $\begin{array}{l}2.784 \\
(0.36)\end{array}$ & $\begin{array}{l}0.400 \\
(0.03)\end{array}$ & $\begin{array}{l}2.392 \\
(0.34)\end{array}$ & $\begin{array}{l}1.353 \\
(0.21)\end{array}$ & $\begin{array}{l}0.578 \\
(0.03)\end{array}$ & $\begin{array}{l}0.298 \\
(0.04)\end{array}$ & $\begin{array}{l}0.254 \\
(0.02)\end{array}$ & $\begin{array}{l}0.609 \\
(0.05)\end{array}$ & $\begin{array}{l}0.789 \\
(0.04)\end{array}$ \\
\hline $\operatorname{scf}$ & $\begin{array}{l}1.996 \\
(0.19)\end{array}$ & $\begin{array}{l}0.275 \\
(0.03)\end{array}$ & $\begin{array}{l}2.034 \\
(0.25)\end{array}$ & $\begin{array}{l}1.130 \\
(0.16)\end{array}$ & $\begin{array}{l}0.670 \\
(0.06)\end{array}$ & $\begin{array}{l}0.342 \\
(0.04)\end{array}$ & $\begin{array}{l}0.346 \\
(0.03)\end{array}$ & $\begin{array}{c}0.619 \\
(0.07)\end{array}$ & $\begin{array}{c}0.742 \\
(0.04)\end{array}$ \\
\hline $\operatorname{tra}$ & $\begin{array}{l}2.725 \\
(0.33)\end{array}$ & $\begin{array}{l}0.273 \\
(0.01)\end{array}$ & $\begin{array}{l}2.560 \\
(0.63)\end{array}$ & $\begin{array}{l}3.180 \\
(0.46)\end{array}$ & $\begin{array}{l}0.378 \\
(0.11)\end{array}$ & $\begin{array}{l}0.318 \\
(0.06)\end{array}$ & $\begin{array}{l}0.289 \\
(0.02)\end{array}$ & $\begin{array}{l}0.693 \\
(0.09)\end{array}$ & $\begin{array}{l}0.755 \\
(0.07)\end{array}$ \\
\hline tre & $\begin{array}{l}2.521 \\
(0.40)\end{array}$ & $\begin{array}{l}0.264 \\
(0.04)\end{array}$ & $\begin{array}{l}2.367 \\
(0.52)\end{array}$ & $\begin{array}{l}3.109 \\
(0.39)\end{array}$ & $\begin{array}{l}0.366 \\
(0.12)\end{array}$ & $\begin{array}{l}0.307 \\
(0.05)\end{array}$ & $\begin{array}{l}0.290 \\
(0.09)\end{array}$ & $\begin{array}{l}0.701 \\
(0.19)\end{array}$ & $\begin{array}{l}0.767 \\
(0.08)\end{array}$ \\
\hline
\end{tabular}

\section{Discussion}

Ecomorphological studies have previously demonstrated that body shape and structures associated with swimming ability are highly correlated with their habitat use (Wikramanayake, 1990; Wainwright et al., 2002) and feeding behavior (Werner, 1977; Webb, 1984; Nunes and Hartz, 2006).

The first principal component of our analyses separated the fish species studied into two groups as a function of their swimming abilities. The first group was composed by M. aureum (mya), M duriventre (myd), P. brachypomus 
Table 3. Summary of Discriminant Analysis Function with Wilks' $\lambda$ and p-values for each ecomorphological attribute.

\begin{tabular}{ccccc}
\hline $\begin{array}{c}\text { Ecomorphological } \\
\text { Attribute }\end{array}$ & Wilks' $\boldsymbol{\lambda}$ & Partial $\boldsymbol{\lambda}$ & F & p-value \\
\hline CI & 0.0025 & 0.7732 & 7.821 & $<0.01$ \\
RD & 0.0024 & 0.7797 & 7.534 & $<0.01$ \\
CPC & 0.0042 & 0.4509 & 32.462 & $<0.01$ \\
PAF & 0.0109 & 0.1745 & 126.167 & $<0.01$ \\
FVI & 0.0034 & 0.5515 & 21.689 & $<0.01$ \\
RWCP & 0.0022 & 0.8857 & 3.439 & $<0.01$ \\
RHCP & 0.0052 & 0.3647 & 46.443 & $<0.01$ \\
RHH & 0.0032 & 0.6024 & 17.600 & $<0.01$ \\
VEP & 0.0024 & 0.7899 & 7.089 & $<0.01$ \\
\hline
\end{tabular}

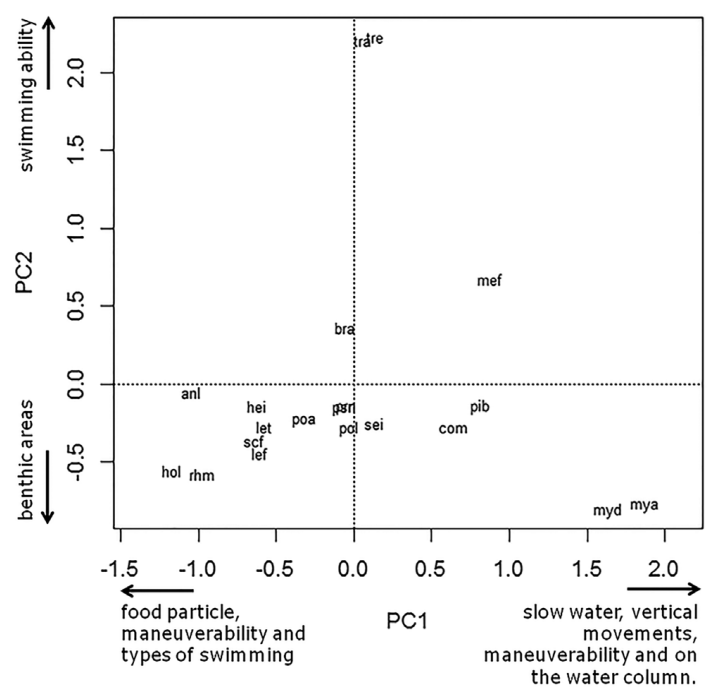

Figure 3. Biplot with the first principal components ordering the fish species as function of the ecomorphological attributes (species codes are in the Table 1).

(pib), C. macropomum (com) and M. festivus (mef). Common morphological characteristics of these species are adipose fins, molariforms teeth and bodies that are high and laterally compressed (Soares et al., 2007). These morphological characteristics are associated mainly with high values of the attributes CI and RD and less straightly with CPC and VEP. These characteristics are typical of species with high maneuverability and the ability to explore aquatic environments with submersed obstacles (Werner, 1977; Gatz Junior, 1979; Gerstner, 1999), such as the macrophytes meadows and flooded forests of the Amazonian floodplains. Juveniles of Mylossoma spp. are known to live in the floodplains macrophyte meadows (Sánchez-Botero et al., 2003), while adults are known to exploit the flooded forest for shelter and food (Goulding, 1979). Araújo-Lima and Goulding (1997) reported that juveniles of $C$. macropomum live in macrophytes meadows. Larger juveniles (greater than $30 \mathrm{~cm}$ ) and adults have been observed in the flooded forest during the flood season. Loubens and Panfili (1997) observed C. macropomum into the flooded forest and savannahs habitats in the headwater of the Madeira River. Previous study suggested that juveniles of $P$. brachypomus live in the floodplains of nutrient-rich rivers, often in macrophytes meadows, while adults live in the flooded forest of the Amazonas River and its nutrient-rich tributaries (Araújo-Lima and Ruffino, 2003). Goulding (1980) noticed that juvenile P. brachypomus $(38-55 \mathrm{~cm})$ exhibited the ability to explore the flooded forest to seek fruits and seeds, while largest individuals were found feeding on leafs and seeds in the floodplain lakes during the drought season. Mesonauta festivus is known to explore the roots of macrophytes meadows of the Amazonian floodplain lakes (Casado del Castillo et al., 2012; Soares et al., 2014).

The second group into which the first principal component separated fish species consisted of the spindle-shaped, elongated and hydrodynamics fish species A. elongatus (anl), R. microlepis (rhm), H. immaculatus (hei), L. trifasciatus (let), S. fasciatum (scf) and L. friderici (lef). There is little information on the ecology of the species belonging to this group. The high estimated indexes of RWCP and RHCP related with width and height of the caudal peduncle respectively are indicators of strong swimming ability. Fish with these ecomophrological characteristics should be able to long duration movements with high performance (Bandyopadhyay et al., 1997; Teixeira and Bennemann, 2007). We hypothesize that these morphological characteristics make this group able to successfully explore the pelagic zones of the Amazonian floodplains lakes' open water. The hydrodynamic body shape of these species should convey a strategic advantage in these areas since there contain no obstacles (Breda et al., 2005).

The second principal component of our analysis determined a distinct position for Triportheus angulatus (tra) and T. elongates (tre) associated with high estimates for the pectoral aspect fin (PAF). Large pectoral fins are typical of good swimmers, which tend to inhabit pelagic zones and sustain long and continuous movements. Fernandes (2006) studied fish migrations at the Central Amazon and observed that this species undergoes lateral migrations between the river channel and the floodplain and longitudinal migrations up river. Yamamoto et al. (2004) showed that $T$. angulatus is omnivorous and we hypothesize 
that these migrations permit it to explore a large spectrum of preys, which become available in accordance with the Amazon's hydrological cycle. The benthonic behavior of $H$. litoralle (hol) and $R$. microlepis (rhm), inclusive in hydrodynamics areas, explains their slight association with FVI attribute, since a ventral flattening could help these species maintain their position at the water column without great swimming effort (Cunico and Agostinho, 2006; Pagotto et al., 2011).

The central position of Brycon amazonicus (bra), Potamorhina altamazonica (poa), Potamorhina latior (pol), Psectrogaster rutiloides (psr), Prochilodus nigricans (prn) and Semaprochilodus insignis (sei) at the principal component plot could be associated with the fusiform body shape of these species. This body shape made them able to explore several areas in the floodplain lakes. With exception of B. amazonicus (bra), this group is composed by detritivorous species belonging to Curimatidae (poa, pol and psr) and Prochilodontidae (prn and sei) families. These species are benthopelagic and explore several habitats of rivers of white and black waters (Saint-Paul et al., 2000; Siqueira-Souza and Freitas, 2004).

In general, our results corroborate the statement that the great fish diversity observed at the Amazon Basin could be associated with the spatial heterogeneity and the fish ability to explore this environment. Nevertheless, our main results showed that maneuverability is a key characteristic of the fish species that lives in Amazonian floodplain lakes.

\section{Acknowledgements}

Financial support for this study was provided by CNPq (Grants 563073/2010-1 and 302430/2012-1) and FINEP (PIATAM project grant 01.06 .1223 .0$)$. Laboratory and logistical support was provided by UFAM.

\section{References}

ALSDORF, D.E., MELACK, J.M., DUNNE, T., MERTES, L.A.K., HESS, L.L. and SMITH, L.C., 2000. Interferometric radar measurements of water level changes on the Amazon floodplain. Nature, vol. 404, no. 6774, pp. 174-177. http://dx.doi. org/10.1038/35004560. PMid:10724167.

ARAÚJO-LIMA, C.A.R.M. and GOULDING, M., 1997. So fruitful a fish: ecology, conservation and aquaculture of the Amazon's tambaqui. New York: Columbia University Press. 19 p.

ARAÚJO-LIMA, C.A.R.M. and RUFFINO, M.L., 2003. Migratory fishes of the Brazilian Amazon. In: J. CAROLSFELD, B. HARVEY, C. ROSS and A. BAER, eds. Migratory fishes of south america: biology, fisheries and conservation status. Canada: The World Bank. p. 223-302.

BANDYOPADHYAY, P.R., CASTRANO, J.M., RICE, J.Q., PHILIPS, R.B., NEDDERMAN, W.H. and MACY, W.K., 1997. Low-speed maneuvering and hydrodynamics of fish and small underwater vehicles. Journal of Fluiding Engineering, vol. 119, no. 1, pp. 136-144. http://dx.doi.org/10.1115/1.2819099.

BATISTA, V.S. and PETRERE JÚNIOR, M., 2003. Characterization of the commercial fish production landed at Manaus, Amazonas
State, Brazil. Acta Amazonica, vol. 33, no. 1, pp. 53-66. http:// dx.doi.org/10.1590/1809-4392200331066.

BREDA, L., OLIVEIRA, E.F. and GOULART, E., 2005. Ecomorfologia de locomoção de peixes com enfoque para espécies neotropicais. Acta Scientiarum. Biological Sciences, vol. 27, pp. 371-381. http://dx.doi.org/10.4025/actascibiolsci.v27i4.1271.

CAMPOS, C.P., GARCEZ, R., CATARINO, M.F., COSTA, G.A. and FREITAS, C.E.C., 2015. Population dynamics and stock assessment of Colossoma macropomum caught in the Manacapuru Lake system (Amazon Basin, Brazil). Fisheries Management and Ecology, vol. 22, no. 5, pp. 400-406. http:// dx.doi.org/10.1111/fme.12139.

CASADO DEL CASTILLO, C.P., SOUZA, M.M., CAMPOS, D.F., SERIQUE, K K.A. and ZUANON, J.A.S., 2012. Ictiofauna associada a macrofitas aquaticas de água lêntica (Lago Catalão) e lótica (Ilha da Marchantaria) na época de vazante, Amazonia Central. Folia Amazonica, vol. 21, pp. 23-32.

CUNICO, A.M. and AGOSTINHO, A.A., 2006. Morphological patterns of fish and their relationships with reservoir hydrodynamics. Brazilian Archives of Biology and Technology, vol. 49, no. 1, pp. 125-134. http://dx.doi.org/10.1590/S1516-89132006000100015.

FERNANDES, C.C., 2006. Lateral migrations of fishes in Amazon floodplains. Ecology Freshwater Fish, vol. 6, no. 1, pp. 36-44. http://dx.doi.org/10.1111/j.1600-0633.1997.tb00140.x.

FREIRE, A.G. and AGOSTINHO, A.A., 2001. Ecomorfologia de oito espécies dominantes da ictiofauna do reservatório de Itaipu (Paraná/Brasil). Acta Limnologica Brasiliensia, vol. 13, pp. 1-9.

FREITAS, C E.C. and GARCEZ, R., 2004. Fish communities of natural channels between floodplain lakes and Solimões-Amazonas River (Amazon - Brazil). Acta Limnologica Brasiliensia, vol. 16, pp. 273-280.

FREITAS, C.E.C., COSTA, E.L. and SOARES, M.G.M., 2005. Ecomorphological correlates of thirteen dominant fish species of Amazonian floodplain lakes. Acta Limnologica Brasiliensia, vol. 17 , pp. 339-347.

FREITAS, C.E.C., SIQUEIRA-SOUZA, F.K., FLORENTINO, A.C. and HURD, L.E., 2014. The importance of spatial scales to analysis of fish diversity in Amazonian floodplain lakes and implications for conservation. Ecology Freshwater Fish, vol. 23, no. 3, pp. 470-477. http://dx.doi.org/10.1111/eff.12099.

FREITAS, C.E.C., SIQUEIRA-SOUZA, F.K., GUIMARÃES, A.R., SANTOS, F.A. and SANTOS, I.L.A., 2010. Interconnectedness during high water maintains similarity in fish assemblages of island floodplain lakes in the Amazonian Basin. Revista Brasileira de Zoologia, vol. 27, pp. 931-938.

FROESE, R. and PAULY, D., 2015 [viewed 16 September 2015]. Fishbase [online]. Available from: http://www.fishbase.org.

GATZ JUNIOR, A.J., 1979. Community organization in fishes as indicated by morphological features. Ecology, vol. 60, no. 4, pp. 711-718. http://dx.doi.org/10.2307/1936608.

GERSTNER, C.L., 1999. Maneuverability of four species of coral-reef fish that differ in body and pectoral-fin morphology. Canadian Journal of Zoology, vol. 77, no. 7, pp. 1102-1110. http://dx.doi.org/10.1139/z99-086.

GOULDING, M., 1979. Ecologia da pesca do rio Madeira. Manaus: CNPq/INPA. 179 p.

GOULDING, M., 1980. The fish and the Forest: explorations in Amazonian Natural History. Berkeley: University of California Press. 280 p. 
HUGUENY, B. and POUILLY, M., 1999. Morphological correlates of diet in an assemblage of West African freshwater fishes. Journal of Fish Biology, vol. 54, no. 6, pp. 1310-1325. http:// dx.doi.org/10.1111/j.1095-8649.1999.tb02057.x.

JUNK, W.J., BAYLEY, P.B. and SPARKS, R.E., 1989. The flood pulse concept in river-floodplain 654 systems. In: D.P. DODGE, ed. Proceedings of the International Large River 655 Symposium (LARS), 14-21 September 1989, Honey Harbour, Ontario, Canada. Ottawa: Department of Fisheries and Oceans, vol. 106, pp. 110-127. Canadian Special Publication of Fishery and Aquatic Science.

KEAST, A. and WEBB, D., 1966. Mouth and body form relative to feeding ecology in the fish sauna of a small lake, Lake Opinicon, Ontario. Journal of the Fisheries Board of Canada, vol. 23, no. 12, pp. 1845-1874. http://dx.doi.org/10.1139/f66-175.

LOUBENS, G. and PANFILI, J., 1997. Biologie de Colossoma macropomum (Teleostei: Serrasalmidae) dans le basin du Mamoré (Amazonie bolivienne). Ichthyological Exploration of Freshwaters, vol. 8, pp. 1-22.

MAZZONI, R., MORAES, M., REZENDE, C.F. and MIRANDA, J.C., 2010. Alimentação e padrões ecomorfológicos das espécies de peixes de riacho do alto rio Tocantins, Goiás, Brasil. Iheringia. Zoologia, vol. 100, no. 2, pp. 162-168. http://dx.doi.org/10.1590/ S0073-47212010000200012.

MÉRONA, B. and RANKIN-DE-MÉRONA, J., 2004. Food resource partitioning in a fish community of the central Amazon floodplain. Neotropical Ichthyology, vol. 2, no. 2, pp. 75-84. http:// dx.doi.org/10.1590/S1679-62252004000200004.

MOTTA, P.J., CLIFTON, K.B., HERNANDEZ, P. and EGGOLD, B.T., 1995. Ecomorphological correlates in ten species of subtropical seagrass fishes: diet and microhabitat utilization. Environmental Biology of Fishes, vol. 44, no. 1-3, pp. 36-60. http://dx.doi.org/10.1007/BF00005906.

NEVES, M.P., DEVARIVA, R.L. and WOLFF, L.L., 2015. Diet and ecomorphological relationships of an endemic, speciespoor fish assemblage in a strem in the Iguaço National Park. Neotropical Ichthyology, vol. 13, no. 1, pp. 245-254. http://dx.doi. org/10.1590/1982-0224-20140124.

NUNES, D.M. and HARTZ, S.M., 2006. Feeding dynamics and ecomorphology of Oligosarcus jenynsii (Gunther, 1864) and Oligosarcus robustus (Menezes, 1969) in the Lagoa Fortaleza, southern Brazil. Brazilian Journal of Biology $=$ Revista Brasileira de Biologia, vol. 66, no. 1A, pp. 121-132. http://dx.doi.org/10.1590/ S1519-69842006000100016. PMid:16680315.

OLIVEIRA, E.F., GOULART, E., BREDA, L., MINTE-VERA, C.V., PAIVA, L R.S. and VISMARA, M.R., 2010. Ecomorphological patterns of the fish assemblage in a tropical floodplain: effect of trophic, spatial and phylogenetic structures. Neotropical Ichthyology, vol. 8, pp. 569-586.

PAGOTTO, J.P.A., GOULART, E., OLIVEIRA, E.F. and YAMAMURA, C.B., 2011. Trophic ecomorphology of Siluriformes (Pisces, Osteichthyes) from a tropical stream. Brazilian Journal of Biology $=$ Revista Brasileira de Biologia, vol. 71, no. 2, pp. 469-479. http://dx.doi.org/10.1590/S1519-69842011000300017. PMid:21755165.

POUILLY, M., LINO, F., BRETENOUX, J.G. and ROSALES, C., 2003. Dietary-morphological relationships in a fish assemblage of the Bolivian Amazonian floodplain. Journal of Fish Biology, vol. 62, no. 5, pp. 1137-1158. http://dx.doi.org/10.1046/j.10958649.2003.00108.x

R CORE TEAM, 2013. R: A language and environment for statistical computing. Vienna: R Foundation for Statistical Computing.
SAINT-PAUL, U., ZUANON, J., VILLACORTA-CORREA, M.A., GARCIA, M., FABRÉ, N.N., BERGER, U. and JUNK, W.J., 2000. Fish communities in central Amazonian white and blackwater floodplains. Environmental Biology of Fishes, vol. 57, no. 3, pp. 235-250. http://dx.doi.org/10.1023/A:1007699130333.

SÁNCHEZ-BOTERO, J.I. and ARAUJO-LIMA, C.A.R.M., 2001. As macrófitas aquáticas como berçário para a ictiofauna da várzea do Rio Amazonas. Acta Amazonica, vol. 31, no. 3, pp. 437-447. http://dx.doi.org/10.1590/1809-43922001313447.

SÁNCHEZ-BOTERO, J.I., LIMA DE FARIAS, M., PIEDADE, M.T. and GARCEZ, D.S., 2003. Ictiofauna associada à áreas submersas das macrófitas aquáticas Eichhornia azurea (SW.) e Eichhornia crassipes (Mart.) no lago Camaleão, Amazônia Central, Brasil. Acta Scientiarum, vol. 25, pp. 369-376.

SANTOS, G.M., FERREIRA, E J.G. and ZUANON, J.A.S., 2006. Peixes comerciais de Manaus. Manaus: IBAMA/PROVÁRZEA. $144 \mathrm{p}$.

SIQUEIRA-SOUZA, F.K. and FREITAS, C.E.C., 2004. Fish diversity of floodplain lakes on the lower stretch of the Solimões river. Brazilian Journal of Biology $=$ Revista Brasileira de Biologia, vol. 64, no. 3A, pp. 501-510. http://dx.doi.org/10.1590/ S1519-69842004000300013. PMid:15622847.

SOARES, M.G.M., COSTA, E.L., SIQUEIRA-SOUZA, F.K., ANJOS, H.D.B., YAMAMOTO, K.C. and FREITAS, C.E.C., 2007. Peixes de lagos do médio rio Solimões. Manaus: EDUA. 176 p.

SOARES, M.G.M., FREITAS, C.E.C. and OLIVEIRA, A.C.B., 2014. Assembleias de peixes associadas aos bancos de macrofitas aquaticas em lagos manejados da Amazônia Central, Amazonas, Brasil. Acta Amazonica, vol. 44, no. 1, pp. 143-152. http://dx.doi. org/10.1590/S0044-59672014000100014.

TEIXEIRA, I. and BENNEMANN, S.T., 2007. Ecomorfologia refletindo a dieta dos peixes em um reservatório no sul do Brasil. Biota Neotropica, vol. 7, no. 2, pp. 67-76. http://dx.doi.org/10.1590/ S1676-06032007000200007.

WAINWRIGHT, P.C., BELLWOOD, D.R. and WESTNEAT, M.W., 2002. Ecomorphology of locomotion in labrid fishes. Environmental Biology of Fishes, vol. 65, no. 1, pp. 47-62. http:// dx.doi.org/10.1023/A:1019671131001.

WATSON, D.J. and BALON, E.K., 1984. Ecomorphological analysis of fish taxocenes in rainforest streams of northern Borneo. Journal of Fish Biology, vol. 25, no. 3, pp. 371-384. http://dx.doi. org/10.1111/j.1095-8649.1984.tb04885.x.

WEBB, P.W., 1984. Form and function in fish swimming. Science, vol. 251 , pp. 58-68.

WERNER, E.E., 1977. Species packing and niche complementarity in three sunfishes. American Naturalist, vol. 111, no. 979, pp. 553-578. http://dx.doi.org/10.1086/283184.

WIKRAMANAYAKE, E.D., 1990. Ecomorphology and biogeography of a tropical stream fish assemblage: Evolution of assemblage structure. Ecology, vol. 71, no. 5, pp. 1756-1764. http://dx.doi.org/10.2307/1937583.

WINEMILLER, K.O., 1991. Ecomorphological diversification in lowland freshwater fish assemblages from five biotic regions. Ecological Monographs, vol. 61, no. 4, pp. 343-365. http://dx.doi. org/10.2307/2937046.

YAMAMOTO, K.C., SOARES, M.G.M. and FREITAS, C.E.C., 2004. Alimentação de Triportheus angulatus (Spix \& Agassiz, 1829) no lago Camaleão, Manaus, AM, Brasil. Acta Amazonica, vol. 34, no. 4, pp. 653-659. http://dx.doi.org/10.1590/S004459672004000400017. 